\title{
Prolylcarboxypeptidase (Angiotensinase C) in Human Lung and Cultured Cells
}

\author{
Kenshi Kumamoto, Tess A. Stewart, Alice R. Johnson, and Ervin G. Erdös, \\ Departments of Pharmacology and Medicine, University of Texas Health Science \\ Center, Dallas, Texas 75235
}

\begin{abstract}
A B S T R A C T The activity of prolylcarboxypeptidase (PCP), or angiotensinase $\mathrm{C}$, was measured in lung tissues, leukocytes, and cultured human cells using $\mathrm{Cbz}$ Pro- $\left[{ }^{14} \mathrm{C}\right]$ Ala as a substrate. A lysosomal fraction of homogenized rat or human lung contained most of the PCP activity in that tissue. Polymorphonuclear neutrophils, macrophages, and lymphocytes isolated from human blood had PCP activity. Fibroblasts cultured from human tissues had the highest activity $(0.56-1.15 \mu \mathrm{mol} /$ $h$ per $10^{6}$ cells), more than endothelial cells cultured from human pulmonary arteries. PCP of cultured human fibroblasts was similar to the human renal enzyme because it was resistant to moderate heating and was not inhibited by $p$-chloromercuriphenyl sulfonic acid. These properties and the substrate specificity distinguish PCP from cathepsin A, which is also in fibroblasts. Antibody to human renal PCP reacted with fibroblast PCP in immunofluorescence, indicating common antigenic determinants. Hydrocortisone changed PCP activity in fibroblasts in parallel with changes in $\beta$-glucuronidase activity and cell-protein concentration; the activity was depressed at low concentration of the hormone. PCP activity was also found in synovial fluid from arthritic joints and in fibroblasts from the synovium. That PCP is found in both inflammatory exudates and in cells that appear at sites of inflammation indicates that, in addition to inactivating angiotensins, this enzyme may have a role in inflammation.
\end{abstract}

\section{INTRODUCTION}

Prolylcarboxypeptidase (peptidyl prolyl-amino acid hydrolase, EC 3.4.12.4) cleaves the C-terminal ProPhe bond in angiotensin II and des-Asp'-angiotensin II (angiotensin III) and also the Pro-Ala bond in the angiotensin II antagonist, $\mathrm{Sar}^{1}-\mathrm{Ala}^{8}$-angiotensin II

Received for publication 27 June 1980 and in revised form 10 September 1980. (saralasin) (1-4). The enzyme was first named angiotensinase $\mathrm{C}$ because it inactivates angiotensin II (1).

Prolylcarboxypeptidase (PCP) ${ }^{1}$ cleaves C-terminal amino acids of short synthetic peptides if they have a free carboxyl group and if they are linked to a penultimate proline. The amino group of proline has to be protected or linked to another amino acid $(2,3)$. PCP has an acidic $\mathrm{pH}$ optimum, but depending upon the structure of the substrate, $20-90 \%$ of the activity is retained at neutral pH (4). PCP is found in human urine and in a lysosomal fraction of homogenized kidney and leukocytes (1-5). The enzyme was purified from hog (6) and human kidneys (4), and was also found in lung and cultured cells (7). We used a recently synthesized, radiolabeled substrate to measure PCP activity in cultured cells, blood cells, and tissues. Fibroblasts cultured from human tissues have the highest PCP activity. These cells were used to study the properties of PCP and factors that affect its activity.

\section{METHODS}

Materials. Cbz-L-Pro-L- $\left[{ }^{14} \mathrm{C}\right] A$ Ala was synthesized by Dr. J. DeGraw of Stanford Research Institute, Palo Alto, Calif., and Dr. E. Wickstrom of the University of Denver, Denver, Colo. Substrates for $\beta$-glucuronidase (EC 3.2.1.31), cathep$\sin$ A (EC 3.4.12-), and other chemicals and inhibitors were purchased from Sigma Chemical Co., St. Louis, Mo., and $\left[{ }^{14} \mathrm{C}\right]$ alanine was from New England Nuclear, Boston, Mass. Materials for cell culture were purchased from Grand Island Biological Co., Grand Island, N. Y., and Microbiological Associates, Inc. Walkersville, Md. Ficoll and Percoll were purchased from Pharmacia Fine Chemicals, Piscataway, N. J. Epidermal and fibroblast growth factors were from Collaborative Research, Inc., Waltham, Mass. Fluorescein isothiocyanate-labeled goat anti-rabbit gamma globulin was from Miles Laboratories, Elkhart, Ind. Dextrans (200,000-300,000 mol wt) were from Nutritional Biochemical Corp. (Cleveland,

${ }^{1}$ Abbreviation used in this paper: PCP, prolylcarboxypeptidase. 
Ohio) and Isolymph was from Gallard-Schlesinger Chemical Mfg. Corp., Carle Place, N. Y.

Tissues. Human lungs were obtained at autopsy within $5 \mathrm{~h}$ of death. Rat lungs were perfused in situ with isotonic saline until the effluent was free of blood.

Lung tissue was taken from peripheral areas of several lobes and diced with scissors in $10 \mathrm{mM}$ Tris/ $\mathrm{HCl}$ ( $\mathrm{pH} 7.4)$ containing $0.35 \mathrm{M}$ sucrose (15\% wt/vol) and homogenized with a Polytron homogenizer (Brinkmann Instruments, Inc. Westbury, N. Y.) for $20 \mathrm{~s}$. Nuclei and cell debris were removed by centrifugation at $500 \mathrm{~g}$ for $10 \mathrm{~min}$. The homogenate was then filtered through gauze and centrifuged at $10,000 \mathrm{~g}$ for $20 \mathrm{~min}$ in a Sorvall RC-5 centrifuge (DuPont Co. Instrument Products Div., Sorvall Biomedical Div., Wilmington, Del.). The pellet was suspended in a volume in milliliters of $0.35 \mathrm{M}$ sucrose equal to the weight in grams of tissue. The supernatant fluid was centrifuged at $105,000 \mathrm{~g}$ for $60 \mathrm{~min}$ in a Beckman L-5-65 ultracentrifuge (Beckman Instruments, Inc. Spinco Div., Palo Alto, Calif.) and the pellet was resuspended in the same volume as above. All samples were stored at $-70^{\circ} \mathrm{C}$ and sonicated for $60 \mathrm{~s}$ immediately before assay.

Cell cultures. Fibroblasts from human foreskin, embryonic lung, umbilical cord skin, and synovium were cultured in medium 199 (Microbiological Associates, Inc. Bethesda, Md.) supplemented with $10 \%$ fetal calf serum, and antibiotics. Cells from foreskin, umbilical cord, and synovium were grown from tissue explants (8). The lung fibroblasts, IMR 90, were obtained from the Institute of Medical Research, Camden, N. J. Endothelial cells were isolated from human pulmonary arteries with collagenase (9) and grown in medium 199 supplemented with $10 \%$ human serum, $20 \%$ fetal calf serum, and antibiotics. All cultures were maintained at $37^{\circ} \mathrm{C}$ in an atmosphere of $5 \% \mathrm{CO}_{2}$ and $95 \%$ air.

Confluent monolayers of cultured cells were used throughout except in experiments with hydrocortisone and polypeptide growth factors. For enzyme assays each flask of cells was rinsed twice with phosphate-buffered saline ( $\mathrm{pH}$ 7.4), and the cells were detached with $0.125 \%$ trypsin in $10 \mathrm{mM}$ Hepesbuffered saline with $1 \%$ glucose ( $\mathrm{pH} 7.4$ ). The cells were centrifuged to a pellet ( $400 \mathrm{~g}$ for $10 \mathrm{~min}$ ) at room temperature and washed twice with Hepes-buffered saline. After the second wash, the cell pellet was resuspended in 1-3 $\mathrm{ml}$ of the same solution.

Blood cells. Polymorphonuclear neutrophils were isolated from peripheral venous blood of healthy individuals by centrifugation (10) on a sodium diatrizoate/Ficoll cushion (Isolymph). Residual erythrocytes were removed from the neutrophil pellet by hypotonic lysis in several samples, but the activity of PCP was unaffected by the presence of erythrocytes.

A similar method was used to prepare mononuclear leukocytes (11). Heparinized venous blood was centrifuged on Isolymph, and the mononuclear cells were recovered from the interface. Approximately 2-3 $\times 10^{7}$ cells were collected for further purification on a discontinuous gradient of polyvinylpyrrolidone-coated colloidal silica (Percoll).

After centrifugation and washing, the lymphocytes were removed from the upper layer, suspended in fresh medium, and plated in glass petri dishes. The nonadherent cells (lymphocytes) were decanted after incubation for $1 \mathrm{~h}$ at $37^{\circ} \mathrm{C}$, seeded in a fresh dish and incubated for $1 \mathrm{~h}$ at $37^{\circ} \mathrm{C}$.

The adherent cells (macrophages) were washed several times with Hanks' solution to remove lymphocytes. The macrophages were then dislodged with a rubber policeman and suspended in fresh medium RPMI.

Synovial fluid. Synovial fluid was collected from knee joints of patients with rheumatoid arthritis. The fluid was drawn into a tube containing 143 Units USP of sodium heparin and centrifuged at $1,000 \mathrm{~g}$ for $5 \mathrm{~min}$ at $4^{\circ} \mathrm{C}$. The supernatant fluid was stored at $-20^{\circ} \mathrm{C}$.

Immunofluorescence. Purified human renal PCP (4) was emulsified in complete Freund's adjuvant in a volume of $1 \mathrm{ml}$ and injected into rabbits. The antiserum was used in a dilution of $1: 20$ for indirect immunofluorescence.

Fibroblasts were plated on glass cover slips for the detection of PCP by fluorescence microscopy. The cover slips were rinsed twice with phosphate-buffered saline ( $\mathrm{pH} 7.4$ ) containing 0.15 $\mathrm{M} \mathrm{NaCl}$ and $2 \mathrm{mM} \mathrm{MgCl}_{2}$ and fixed with $3 \%$ formaldehyde. One of each pair was treated with $0.05 \%$ Triton X-100 in phosphate-buffered saline for $5 \mathrm{~min}$ at $10^{\circ} \mathrm{C}$. This step permits penetration of the antibody into the cells. The cover slips were rinsed twice with buffer, rabbit antiserum to human renal PCP was added, and they were incubated for $1 \mathrm{~h}$ at $37^{\circ} \mathrm{C}$. Controls were treated with normal (nonimmune) rabbit serum. All cover slips were washed twice, and fluorescein-isothiocyanate-labeled boat anti-rabbit gamma globulin was added. After a second incubation at $37^{\circ} \mathrm{C}$ for $60 \mathrm{~min}$, the cover slips were washed, mounted on glass slides, and inspected with a Leitz fluorescence microscope (E. Leitz, Inc., Rockleigh, N. J.).

Cell growth factors. The effect of hydrocortisone and epidermal or fibroblast growth factors on PCP was investigated with subconfluent monolayers of IMR-90 fibroblasts. Actively growing cells $(30-50 \%$ confluent) were treated with epidermal or fibroblast growth factor $(10 \mathrm{ng} / \mathrm{ml})$ or hydrocortisone $(0.1 \mathrm{mM}-1 \mu \mathrm{M})$ for $96 \mathrm{~h}$ at $37^{\circ} \mathrm{C}$. The cultures remained undisturbed during this time and the medium was not changed. Triplicate dishes were prepared for each treatment or for controls that were treated only with standard culture medium. On the day of the assay, cells were detached with $0.125 \%$ trypsin and sonicated for $60 \mathrm{~s}$ at $4^{\circ} \mathrm{C}$. The lysed cells were centrifuged at $3,000 \mathrm{~g}$ for $10 \mathrm{~min}$ and the supernatant fluid was assayed for PCP activity.

PCP assay. The activity of PCP was determined by measuring the hydrolysis of Cbz-Pro-Ala at $\mathrm{pH} \mathrm{5.0.} \mathrm{The} \mathrm{reaction}$ mixture consisted of $0.1 \mathrm{ml}$ substrate, $0.02-0.1 \mathrm{ml}$ enzyme, and $0.2 \mathrm{M}$ sodium acetate buffer ( $\mathrm{pH} 5.0$ ) containing $0.3 \%$ neomycin sulfate in a final volume of $0.3 \mathrm{ml}$. The substrate solution consisted of 20 parts of $0.12 \mathrm{Cbz}$-Pro-Ala to one part of $6 \mathrm{mM}$ $\mathrm{Cbz}$-Pro- $\left[{ }^{14} \mathrm{C}\right] \mathrm{Ala}$. The final concentration of substrate in the reaction mixture was $40 \mathrm{mM}$ with an average $26,000 \mathrm{cpm}$. The enzyme was incubated with substrate at $37^{\circ} \mathrm{C}$ for $1-18 \mathrm{~h}$. The reaction was stopped with $0.2 \mathrm{~N} \mathrm{HCl}$. The reaction rate was linear until $30 \%$ of the substrate was consumed. After termination of the reaction, unhydrolyzed substrate was extracted with $4 \mathrm{ml}$ of a mixture of chloroform and 1-butanol $(4: 1)$ and $\left[{ }^{14} \mathrm{C}\right]-$ Ala in the aqueous phase was measured in a scintillation counter. All samples were assayed in duplicate.

$\beta$-Glucuronidase assay. $\beta$-Glucuronidase was determined with $p$-nitrophenyl- $\beta$-D-glucuronide as substrate using $0.1 \mathrm{ml}$ of fractions from cells or tissues in sodium acetate buffer ( $\mathrm{pH} \mathrm{4.0)}$. The $p$-nitrophenol released was determined by reading the optical density at $405 \mathrm{~nm}$ in a spectrophotometer (12).

Cathepsin A assay. Cathepsin A activity was measured using Cbz-Glu-Tyr as the substrate (4). The reaction mixture contained $0.1 \mathrm{ml}$ of $0.2 \mathrm{~N}$ sodium acetate buffer ( $\mathrm{pH} 5.0$ ), 0.1 $\mathrm{ml}$ of enzyme, and $10 \mathrm{mM} \mathrm{Cbz-Glu-Tyr}$. The samples were incubated at $37^{\circ} \mathrm{C}$ for $1-3 \mathrm{~h}$, and the reaction was stopped by adding $3 \%$ sulfosalicylic acid. The tyrosine released into the supernatant fluid was measured in an amino acid analyzer (model 121 Beckman Instruments).

Other techniques. Protein concentration was determined by the method of Lowry et al. (13) with bovine serum albumin as a standard. Cell number was determined by counting 
TABLE I

Distribution of PCP and $\beta$-Glucuronidase Activity in Fractions of Homogenized Human and Rat Lung

\begin{tabular}{|c|c|c|c|c|c|}
\hline \multirow[b]{2}{*}{ Fraction } & \multirow[b]{2}{*}{$\begin{array}{l}\text { Human lung } \\
\text { activity }\end{array}$} & \multicolumn{2}{|c|}{ PCP } & \multicolumn{2}{|c|}{$\beta$-glucuronidase } \\
\hline & & $\begin{array}{l}\text { Specific } \\
\text { activity }\end{array}$ & $\begin{array}{l}\text { Rat lung } \\
\text { activity }\end{array}$ & $\begin{array}{l}\text { Specific } \\
\text { activity }\end{array}$ & $\begin{array}{l}\text { Rat lung } \\
\text { activity }\end{array}$ \\
\hline & $\%$ & $\mu \mathrm{mol} / \mathrm{h} / \mathrm{mg}$ & $\%$ & $\mu \mathrm{mol} / \mathrm{h} / \mathrm{mg}$ & $\%$ \\
\hline \multicolumn{6}{|l|}{ Homogenate } \\
\hline Supernatant fluid, $500 \mathrm{~g}$ & 100 & 0.18 & 100 & 0.20 & 100 \\
\hline Supernatant fluid, $10,000 \mathrm{~g}$ & 31 & 0.12 & 19 & 0.07 & 31 \\
\hline Precipitate, $10,000 \mathrm{~g}$ & 46 & 0.43 & 62 & 0.63 & 48 \\
\hline Supernatant fluid, $105,000 \mathrm{~g}$ & 16 & 0.09 & 5 & 0.06 & 11 \\
\hline Precipitate, $105,000 \mathrm{~g}$ & 5 & 0.16 & 3 & 0.16 & 3 \\
\hline
\end{tabular}

intact, suspended cells in a ZBI Coulter counter (Coulter Electronics, Inc., Hialeah, Fla.).

Analysis of data. The data were expressed as mean values \pm SEM, and significance of difference was estimated by Student's $t$ test. Least-square regression analysis was used to determine best-fit lines for correlation.

\section{RESULTS}

PCP in tissues and cells. We used a new radioactive substrate to measure PCP activity in tissues and cultured cells. The activity of PCP in the crude homogenate of human or rat lung was 0.18 and $0.20 \mu \mathrm{mol}$ of Cbz-Pro- $\left[{ }^{14} \mathrm{C}\right]$ Ala cleaved per milligram of protein per hour. When lung homogenates were fractionated by centrifugation, $62 \%$ of the total activity in rat lungs (Table I) and $46 \%$ of the total activity in human lungs sedimented in the lysosomal fraction. The same fraction in rat contained $48 \%$ of the lysosomal marker enzyme, $\beta$-glucuronidase. The final supernatant fluid and precipitate (microsomal fraction) had only $3-5 \%$ of the total PCP activity in rat lung and $5-16 \%$ in human lung.

TABLE II

PCP Activity in Human Cells

\begin{tabular}{lrc}
\hline \multicolumn{1}{c}{ Enzyme source } & $n^{*}$ & Activity \\
\hline Blood cells & & $\mu$ mol/h/10 cells \\
$\quad$ Polymorphonuclear neutrophils & 4 & $0.08 \pm 0.02$ \\
Lymphocytes & 6 & $0.15 \pm 0.07$ \\
Macrophages & 5 & $0.23 \pm 0.08$ \\
Cultured cells & & \\
Fibroblasts (umbilical cord) & 3 & $0.56 \pm 0.15$ \\
Fibroblasts (lung) & 3 & $0.76 \pm 0.05$ \\
Fibroblasts (foreskin) & 26 & $0.93 \pm 0.20$ \\
Fibroblasts (synovium) & 2 & $0.67,1.15$ \\
Endothelial cells (pulmonary artery) & 3 & $0.24 \pm 0.08$
\end{tabular}

Data are expressed as mean $\pm \mathrm{SEM}$.

$* n$ represents number of experiments.

‡ Cultured from 52-yr-old white male rheumatoid arthritis patient.
To determine whether PCP in human lung originates from the tissues or from leukocytes trapped within the lung, we measured the enzyme activity of human cells collected from peripheral blood or grown in tissue culture (Table II). Neutrophil granulocytes had the lowest activity among the blood cells tested, $0.08 \mu \mathrm{mol} / \mathrm{h}$ per $10^{6}$ cells. Lymphocytes and macrophages were more active. Lymphocytes cleaved $0.15 \mu \mathrm{mol} / \mathrm{h}$ per $10^{6}$ cells of substrate and macrophages $0.23 \mu \mathrm{mol} / \mathrm{h}$ per $10^{6}$ cells of substrate.

Cells cultured from tissues or blood vessels also had PCP activity. Pulmonary arterial endothelial cells had approximately the same activity as macrophages $(0.24$ $\mu \mathrm{mol} / \mathrm{h}$ per $10^{6}$ cells). Fibroblasts were the most active of all the cells tested. Fibroblasts from embryonic lung, umbilical cord skin, foreskin, and synovium had PCP activity from $0.56-1.15 \mu \mathrm{mol} / \mathrm{h}$ per $10^{6}$ cells.

Characteristics of PCP in fibroblasts. The properties of PCP extracted from cultured human foreskin fibroblasts were similar to those of the purified human kidney enzyme (4). The fibroblast enzyme, just as renal PCP, was resistant to moderate heating $\left(60^{\circ} \mathrm{C}\right)$ and was inhibited by $p$-phenylmethyl-sulfonylfluoride, but not by the $\mathrm{SH}$ enzyme inhibitor, $p$-chloromercuriphenyl sulfonic acid (Table III). Chloroquine inhibited PCP in a dose-related manner; $30 \%$ of the activity was inhibited at $0.1 \mathrm{mM}$ and $70 \%$ was inhibited at $1 \mathrm{mM}$ concentration of the inhibitor. Adding the substrate cathep$\sin \mathrm{A}(\mathrm{Cbz}-\mathrm{Glu}-\mathrm{Tyr})$ to the reaction mixture did not inhibit the hydrolysis of Cbz-Pro-Ala by PCP. Since Cbz-Glu-Tyr is not a competitive substrate, cathepsin $A$ and PCP activities are due to different enzymes. However, fibroblasts have cathepsin $A$ activity because the cells cleaved Cbz-Glu-Tyr at a rate of $1.17 \pm 0.4$ $\mu \mathrm{mol} / \mathrm{h}$ per $10^{6}$ cells. Like cathepsin $\mathrm{A}$ in other tissues (4), the fibroblast enzyme was inhibited $70 \%$ by $1 \mathrm{mM}$ $p$-chloromercuriphenyl sulfonic acid, and $95 \%$ of the activity was lost when the cells were heated to $60^{\circ} \mathrm{C}$ for $30 \mathrm{~min}$.

Immunofluorescence. $\mathrm{PCP}$ in fibroblasts has antigenic determinants in common with kidney PCP be- 
TABLE III

Percent Inhibition or Inactivation of PCP and Cathepsin A Activity of Cultured Human Foreskin Fibroblasts

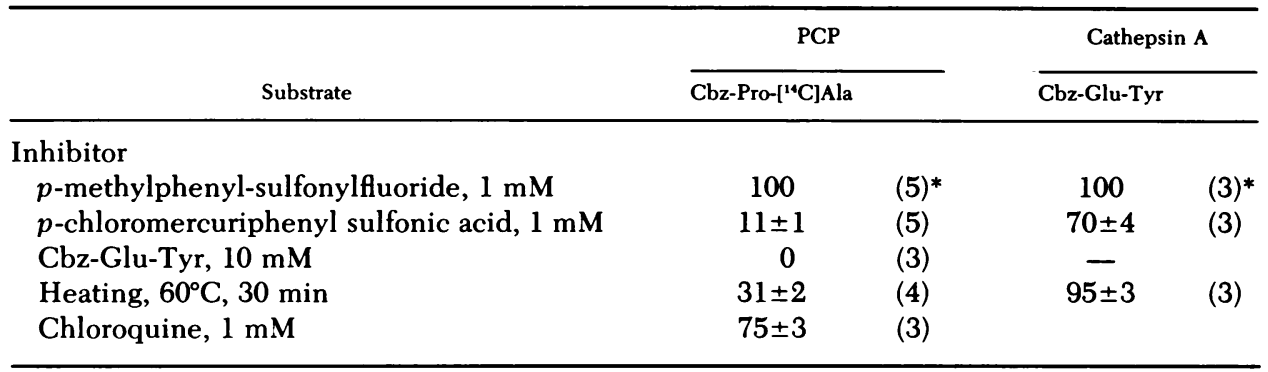

Data are mean \pm SEM.

* Numbers in parentheses represent number of experiments.

cause rabbit antiserum to purified human renal PCP reacted with the fibroblast enzyme (Fig. 1). The fluorescence from anti-PCP developed with fluorescein isothiocyanate-labeled anti-rabbit gamma globulin was distributed throughout the cells. Preimmunized rabbit serum produced only a faint background fluorescence. In cells not treated with Triton X-100 before application of the antibody to PCP there was little fluorescence, indicating that most of the enzyme is inside the cells.

Growth factors and hydrocortisone. Neither epidermal nor fibroblast growth factor affected the PCP activity in actively growing fibroblasts, although they increased the cell number by $30-40 \%$. The activity of PCP in growth factor-treated cells ranged from 97$115 \%$ of the control (untreated) cell activity.

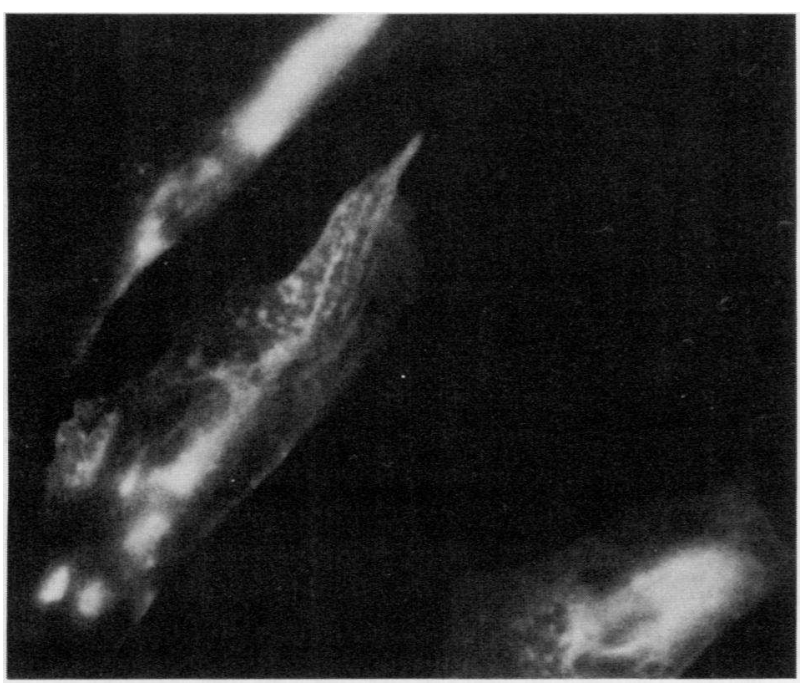

FIGURE 1 PCP in fibroblasts cultured from human foreskin. The immunofluorescence reaction was produced by treating cells with rabbit antibody to human renal PCP and then with fluorescein isothiocyanate-labeled goat anti-rabbit gamma globulin.
When the fibroblasts were cultured in medium with hydrocortisone at a concentration of $2 \mu \mathrm{M}, \mathrm{PCP}$ activity per cell decreased. Activity increased with higher concentrations of the drug (Fig. 2). The changes in PCP activity by hydrocortisone were accompanied by parallel changes in $\beta$-glucuronidase activity $(r=0.965$, $n=12, P<0.001$ ). These data are shown in Fig. 3. Hydrocortisone treatment of the fibroblasts caused similar changes in protein concentration in the cells $(r$ $=0.961, n=12, P<0.001)$ but the data are not shown.

PCP in synovial fluid. The substrates of PCP are proline peptides, and both leukocytes and fibroblasts have PCP activity. This enzyme could appear at sites of inflammation in connective tissues, such as in joints of patients with rheumatoid arthritis. The PCP activity in synovial fluids from five rheumatoid knee joints was $0.38 \pm 0.04 \mu \mathrm{mol} / \mathrm{h}$ per $\mathrm{ml}$. Maximum activity was obtained when 5- $\mu$ l aliquots of synovial fluid were used as a source of enzyme in the reaction mixtures. Activity decreased when larger volumes of fluid were used

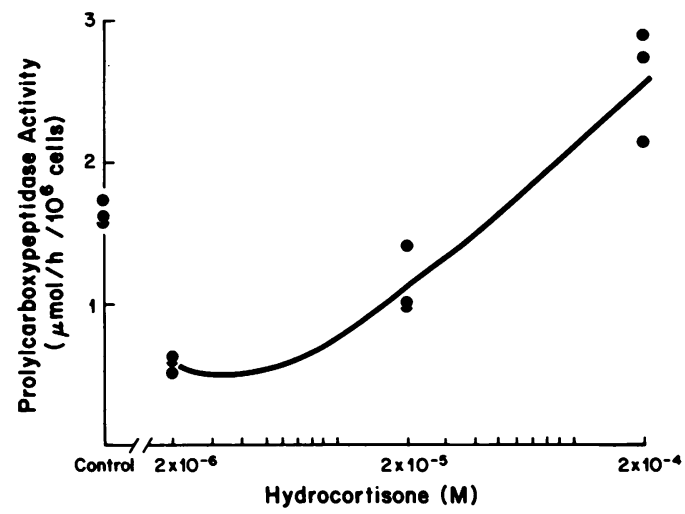

FIGURE 2 Effect of hydrocortisone on PCP activity in cultured fibroblasts. Hydrocortisone was added to the culture medium $96 \mathrm{~h}$ before the enzyme activity was measured. The concentration of hydrocortisone is given on the abscissa and the enzyme activity is given on the ordinate. 


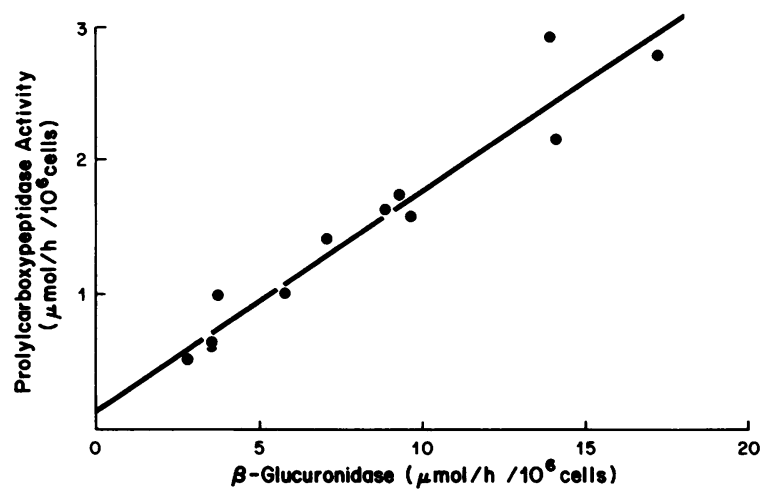

FIGURE 3 Correlation between activity of $\beta$-glucuronidase and activity of PCP in cultured fibroblasts treated with hydrocortisone. The activity of $\beta$-glucuronidase is on the abscissa and activity of PCP is on the ordinate. $r=0.965, n=12$, $P<0.001$.

without dilution, indicating the presence of a reversible inhibitor.

\section{DISCUSSION}

PCP was first identified in kidney, urine, and leukocytes (1-5); low PCP activity was also detected in rat liver and bovine spleen $(14,15)$. Research on this enzyme has been hampered by the lack of a simple, sensitive assay. When studies with substrates of human renal PCP indicated that Cbz-Pro-Ala was cleaved four times faster than Cbz-Pro-Phe (4), radiolabeled Cbz-Pro-Ala was synthesized. This provided the basis for a sensitive assay that we applied to study PCP in human cells and tissues.

We found appreciable amounts of the enzyme in lysosomal fractions from human or rat lungs. The enzyme is also present in human cells isolated from peripheral venous blood, in cultured fibroblasts, and pulmonary endothelial cells.

PCP activity was initially detected in polymorphonuclear neutrophils $(2,4,5)$, but both lymphocytes and macrophages have higher activity than neutrophils. The presence of PCP in neutrophils, coupled with the fact that the enzyme has an acidic pH optimum $(1,2,4)$, suggests that the enzyme may have a role in inflammation. Since PCP cleaves peptide bonds only when the penultimate amino acid is proline (1-4), it may cleave peptides from connective tissues.

PCP in the lung may be involved in angiotensin metabolism. Usually angiotensin II is not inactivated within the pulmonary circulation, but Bakhle and Vane (16) found that when isolated perfused lungs developed edema, angiotensin II was inactivated before it left the pulmonary circulation. Thus the peptide must be hydrolyzed either by enzymes released from damaged endothelial cells (17) or by enzymes within the tissues.
Angiotensin III (des-Asp'-angiotensin II) is cleaved by PCP more readily than angiotensin II (4), and the presence of PCP in pulmonary vessels may prevent angiotensin III from entering the systemic circulation. Indeed, Gaynes et al. (18) found that very little labeled angiotensin III escapes passage through the pulmonary vascular bed.

Fibroblasts cultured from several tissues had two to three times more PCP activity than pulmonary arterial endothelial cells. Thus, the PCP activity in lung is mainly due to PCP presence in parenchymal tissues. The properties of fibroblast PCP are similar to those of PCP purified from human kidney (4) with respect to pH optimum, substrate specificity, and sensitivity to heating and chemical inhibitors. In addition, there are common antigenic determinants between the fibroblast and renal enzymes, as indicated by our immunofluorescence experiments.

Cathepsin $\mathrm{A}$ is another enzyme with an acidic $\mathrm{pH}$ optimum that can cleve $\mathrm{Phe}^{8}$ of angiotensin II (19), but it differs from PCP in many respects $(1,2,4,20-23)$. Cultured human fibroblasts have cathepsin A activity, but its substrate specificity, inactivation by heating, and inhibition by $p$-chloromercuriphenyl sulfonic acid $(20,21)$ distinguish it from PCP.

PCP activity in cultured fibroblasts remained constant between the third and tenth passages in culture. The enzymic activity in IMR-90 lung fibroblasts was unaffected by either epidermal or fibroblast growth factors, although these polypeptide growth factors stimulated cell replication. In contrast, hydrocortisone influenced both cell growth and PCP activity. Low concentrations of the steroid $(2 \mu \mathrm{M})$ decreased PCP activity relative to that in untreated cells, but at higher concentrations $(0.2 \mathrm{mM})$ the enzyme activity was increased. The activity of another enzyme, $\beta$-glucuronidase was affected similarly by hydrocortisone, and at all concentrations of the steroid, the enzyme activities were proportional to the cell-protein concentration. The decreased PCP activity at a low concentration of hydrocortisone may be because of stimulated cell replication (24), since the enzyme activity is expressed relative to the cell number. The apparent increase in PCP activity in cells treated with higher concentrations of the steroid probably reflects an inhibition of DNA synthesis and thus, cell replication $(25,26)$.

Fibroblasts cultured both from synovium and synovial fluid from rheumatic joints have PCP activity. The activity in synovial fluid was enhanced by dilution, which suggests that it also contains an inhibitor of PCP.

These experiments show that PCP has a wider distribution than was originally thought. The development of a sensitive and accurate assay for PCP enabled us to examine the enzyme in various tissues and cultured cells. The presence of PCP in such diverse cells as macrophages, lymphocytes, endothelial cells, 
and fibroblasts suggests that this enzyme has other functions in addition to the inactivation of angiotensins.

\section{ACKNOWLEDGMENTS}

We are grateful to Mrs. Katy Hammon, Mrs. Manorama John, and Ms. Anna Siler for their expert assistance. We thank Dr. Stanley Cohen of the Department of Medicine for providing samples of synovial fluid and synovium. We thank Dr. Woodring Wright of the Departments of Cell Biology and Medicine for providing the IMR 90 cells, and Dr. Ellyn Oshida of the Department of Medicine for providing the lymphocytes and macrophages used in these studies. We are also grateful to Dr. Rolland Reynolds of the Department of Pathology for his help with fluorescence microscopy and photography.

This work was supported by grants HL 20594, HL 14187, HL 16320, and HL 18826 from the National Institutes of Health and by contract N00014-75-C0807 from the Office of Naval Research.

\section{REFERENCES}

1. Yang, H. Y. T., E. G. Erdös, and T. S. Chiang. 1968. New enzymatic route for the inactivation of angiotensin. $\mathrm{Na}$ ture (Lond.). 218: 1224-1226.

2. Yang, H. Y. T., E. G. Erdös, T. S. Chiang, T. A. Jenssen, and J. G. Rodgers. 1970. Characteristics of an enzyme that inactivates angiotensin II (angiotensinase C). Biochem. Pharmacol. 19: 1201-1211.

3. Yang, H. Y. T., and E. G. Erdös. 1971. Prolylcarboxypeptidase: a recently described lysosomal enzyme. In Immunopathology of Inflammation. B. K. Forscher and J. C. Houck, editors. Experta Medica, Amsterdam. 146-168.

4. Odya, C. E., D. Marinkovic, K. J. Hammon, T. A. Stewart, and E. G. Erdös. 1978. Purification and properties of prolylcarboxypeptidase (angiotensinase C) from human kidney. J. Biol. Chem. 253: 5927-5931.

5. Sorrells, K., and E. G. Erdös. 1971. Prolylcarboxypeptidase (angiotensinase $\mathrm{C}$ ) in subcellular particles of leukocytes. Fed. Proc. 30: 600. (Abstr.)

6. Kakimoto, T., G. Oshima, H. S. J. Yeh, and E. G. Erdös. 1973. Purification of lysosomal prolylcarboxypeptidase angiotensinase C. Biochim. Biophys. Acta. 302: 178-182.

7. Kumamoto, K., T. A. Stewart, A. R. Johnson, and E. G. Erdös. 1980. Angiotensinase C (prolylcarboxypeptidase) in tissues and cells. Fed. Proc. 39: 321. (Abstr.)

8. Taylor, H. A., G. H. Thomas, C. S. Miller, T. E. Kelly, and D. Siggers. 1973. Mucolipidosis III (pseudo-Hurler polydystrophy): cytological and ultrastructural observations of cultured fibroblasts cells. Clin. Genet. 4: 388-397.

9. Johnson, A. R. 1980. Human pulmonary endothelial cells in culture: activities of cells from arteries and cells from veins. J. Clin. Invest. 65: 841-850.

10. Boyum, A. 1968. Isolation of mononuclear cells and granu- locytes from human blood. Scand. J. Clin. Lab. Invest. 21 (Suppl. 97): 77-89.

11. Rosenbert, S. A., and P. E. Lipsky. 1979. Monocyte dependence of pokeweed mitogen-induced differentiation of immunoglobulin-secreting cells from human peripheral blood mononuclear cell. J. Immunol. 122: 926-931.

12. Fishman, W. H. 1974. $\beta$-Glucuronidase. In Methods of Enzymatic Analysis. H. U. Bergmeyer, editor. Academic Press, Inc., New York. 2nd edition. 2: 929-943.

13. Lowry, O. H., N. J. Rosebrough, A. L. Farr, and R. J. Randall. 1951. Protein measurement with the Folin phenol reagent. J. Biol. Chem. 193: 265-275.

14. McDonald, J. K., B. B. Zeitman, and S. Ellis. 1972. Detection of a lysosomal carboxypeptidase and a lysosomal dipeptidase in highly purified dipeptidyl aminopeptidase I (cathepsin C) and the elimination of their activities from preparations used to sequence peptides. Biochem. Biophys. Res. Commun. 46: 62-70.

15. McDonald, J. K., B. B. Zeitman, P. X. Callahan, and S. Ellis. 1974. Angiotensinase activity of dipeptidyl aminopeptidase I (cathepsin C) of rat liver. J. Biol. Chem. 249: 234-240.

16. Bakhle, Y. S., and J. R. Vane. 1974. Pharmacokinetic function of the pulmonary circulation. Physiol. Rev. 54: 1007-1045.

17. Johnson, A. R., and E. G. Erdös. 1977. Metabolism of vasoactive peptides by human endothelial cells in culture: angiotensin I converting enzyme (kininase II) and angiotensinase. J. Clin. Invest. 59: 684-695.

18. Gaynes, R. P., J. P. Szidon, and S. Oparil. 1978. In vivo and in vitro conversion of des-1-Asp angiotensin $I$ to angiotensin III. Biochem. Pharmacol. 27: 2871-2877.

19. Logunov, A. I., and V. N. Orekhovich. 1972. Isolation and some properties of cathepsin A from bovine spleen. Biochem. Biophys. Res. Commun. 46: 1161-1168.

20. Matsunaga, M. 1971. Nature of lysosomal angiotensinase activity. Jpn. Circ. J. 35: 333-338.

21. Bowen, D. M., and A. N. Davison. 1973. Cathepsin A in human brain and spleen. Biochem. J. 131: 417-419.

22. Doi, E. 1974. Stabilization of pig kidney cathepsin A by sucrose and chloride ion, and inhibition of the enzyme activity by diisopropyl fluorophosphate and sulfhydryl reagents. J. Biochem. 75: 881-887.

23. Doi, E., Y. Kawamura, T. Matoba, and T. Hata. 1974. Cathepsin A of two different molecular sizes in pig kidney. J. Biochem. (Tokyo). 75: 889-894.

24. Grove, G. L., and J. V. Cristofalo. 1977. Characterization of the cell cycle of cultured human diploid cells: effects of aging and hydrocortisone.J. Cell. Physiol. 90: 415-422.

25. Maca, R. D., G. L. Fry, and J. C. Hoak. 1978. The effects of glucocorticoids on cultured human endothelial cells. Br. J. Haematol. 38: 501-509.

26. Smith, B. T., and C. J. P. Giroud. 1975. Effects of cortisol on serially propagated fibroblast cell cultures derived from the rabbit fetal lung and skin. Can.J. Physiol. Pharmacol. 53: 1037-1041. 